Ethos : Jurnal Penelitian dan Pengabdian kepada Masyarakat, Vol 7, No.1, Januari 2019: 121-128

\title{
Peningkatan Keterampilan Organisasi Di Bidang Mixed Reality Komunitas Augmented REALITY DI UNIVERSITAS TrILOGI
}

\author{
${ }^{1}$ Budi Arifitama, ${ }^{2}$ Ade Syahputra \\ ${ }^{1,2}$ Teknik Informatika,Universitas Trilogi, Jl.TMP Kalibata No.1 Kampus Trilogi Jakarta \\ E-mail : ${ }^{1}$ budiarif@trilogi.ac.id, ${ }^{2}$ adesyahputra@trilogi.ac.id
}

\begin{abstract}
The partners of this community service activity are members of the augmented reality community located in the Pancoran area South of Jakarta. The augmented reality community has been running for almost 3 years, initiated by 2013 by the informatics students at the trilogi university with a total of 12 community members. However, unfortunately the activities that have been carried out is not optimal, the meeting schedule are carried out incidentally and has not been scheduled properly. A good community is measured by how active and disciplined the members and administrators of the community. A solution is needed in terms of good organizational management from the community committee as well as good technical capabilities of each member. The solutions given to overcome these problems are (a) Conducting a good organizational management training in managing an organization starting from planning, scheduling, implementing and organizing (b) Conducting basic augmented reality training for members of the community. The results of this training activity resulted in a 100 percent improvement in the abilities and management skills of mixed reality organizations from members of the augmented reality community.
\end{abstract}

Keywords : Augmented Reality, Community Service Development, Skill Improvement, Information Improvement, Organizational Management.

\begin{abstract}
Abstrak. Mitra dari kegiatan pegabdian kepada masyarakat ini adalah angggota dari komunitas augmented reality yang berlokasi di daerah Pancoran Jakarta Selatan. Komunitas Augmented reality telah berjalan kurang lebih hampir 3 tahun lamanya diprakarsai oleh mahasiswa teknik informatika angkata 2013 universitas trilogi dengan total sebanyak 12 anggota komunitas. Namun, sayangnya kegiatan yang selama ini dilakukan belum optimal, jadwal pertemuan dilaksanakan secara insidentil dan belum terjadwal dengan baik yang mengakibatkan pengelolaan dari komunitas menjadi vakum. Sebuah komunitas yang baik diukur dari seberapa aktif dan disiplin dari pelaksana dan pengurus dari komunitas tersebut. Dibutuhkan sebuah solusi dalam hal manajemen organisasi yang baik dari panitia komunitas serta kemampuan teknis yang baik dari setiap member agar dapat mempersiapkan diri untuk ekspansi komunitas ke luar dari universitas. Solusi yang diberikan untuk mengatasi permasalahan tersebut adalah (a)Melakukan pelatihan manajemen organisasi yang baik dalam mengelola sebuah organisasi mulai dari perencanaan, penjadwalan, pelaksanaan dan tata kelola organisasi (b)Melakukan pelatihan dasar augmented reality bagi anggota tetap maupun anggota baru yang belum memiliki keterampilan. Hasil dari kegiatan pelatihan ini menghasilkan 100 persen peningkatan kemampuan dan keterampilan manajemen organisasi mixed reality dari anggota Komunitas Augmented Reality. Kata Kunci : Augmented Reality, Pengabdian Masyarakat, Peningkatan Keterampilan, Peningkatan Pengetahuan, Manajemen Organisasi
\end{abstract}




\section{Pendahuluan}

Pengabdian kepada masyarakat merupakan salah satu dharma atau tugas pokok dari dosen di perguruan tinggi, termasuk di Universitas Trilogi, disamping pengajaran dan penelitian. Pengabdian masyarakat merupakan kegiatan yang memanfaatkan ilmu pengetahuan dalam upaya memberikan sumbangan demi kemajuan masyarakat. Pengertian mengenai pengabdian masyarakat secara filosofis sesungguhnya dapat berkembang dan dikembangkan sesuai dengan persepsi dan tergantung pada dimensi ruang dan waktu. Topik dari pengabdian masyarakat yang berjudul "Peningkatan Keterampilan dan Kemampuan Organisasi di Bidang Mixed Reality Untuk Anggota Komunitas Augmented Reality di Universitas Trilogi" diambil, dikarenakan tim pelaksana pengabdian memiliki latar belakang dan keilmuan yang dibutuhkan untuk menjawab permasalahan yang dimiliki di lokasi mitra pengabdian yaitu kemampuan manajemen organisasi dan teknologi augmented reality yang digunakan oleh pihak mitra.

\section{Analisis Situasi}

Mitra pada program ini adalah Komunitas Augmented Reality (KAR) yang berlokasi di daerah Pancoran Jakarta Selatan. Sebagai sasaran dari program ini adalah para panitia pelaksana komunitas dan anggota tetap maupun baru dari komunitas augmented reality, sebagai upaya untuk meningkatkan kemampuan berorganisasi dari panitia dan keterampilan dari anggota komunitas. Komunitas Augmeneted Reality (KAR) terbentuk sejak pada tahun 2014, selama berdiri telah melaksanakan berbagai kegiatan yang menunjang pengetahuan dari teknologi augmented reality, seperti mengikuti kontes nasional lomba augmented reality di tahun 2015, melaksanakan pertemuan sharing session di tahun 2016, malaksanakan kegiatan seminar mixed reality di tahun 2017. Anggota di komunitas augmented reality ( KAR) saat ini berjumlah 12 member tetap berjenis kelamin pria semuanya. Usia dari para member memiliki rentang mulai dari 17 tahun hingga 22 tahun, pendidikan terendah dari para anggota adalah SMA/SMK.

\section{Permasalahan}

Kurangnya kemampuan dari panitia pengelola dari Komunitas Augmented Reality (KAR) merupakan permasalahan pertama yang ada di mitra. Perilaku manajemen organisasi yang baik belum mampu diterapkan oleh pengelola, mulai dari perencanaan kegiatan, penyusunan proposal, pendelegasian anggota panitia serta manajemen waktu kegiatan komunitas. Dari permasalahan manaejemen organisasi , berdampak pada permasalahan lainnya yaitu kurang terampilnya anggota komunitas secara teknis dengan teknologi augmented reality. Keterbatasan-ketebatasan yang telah disebutkan sebelumnya menjadi penyebab dari kurang optimalnya pelaksanaan kegiatan komunitas. Berdasarkan uraian sebelumnya, maka dapat dirumuskan beberapa permasalahan yaitu: 
-Bagaimana meningkatkan kemampuan manajemen organisasi dari komunitas?

-Bagaimana meningkatkan keterampilan teknis augmented reality dari anggota komunitas?

Secara garis besar, pelaksanaan program pengabdian ini dilaksanakan untuk membantu pelaksana dan anggota komunitas dalam meningkatan kemampuan dan keterampilan pengelolaan organisasi di bidang mixed reality.

\section{Metode Pengabdian}

$$
\text { Pelaksanaan program }
$$
pengabdian kepada masyarakat ini , dilaksanakan dengan cara memberikan pelatihan secara bertahap, sesuai dengan kebutuhan dari mitra komunitas. Pelatihan yang diberikan dapat berupa pendampingan seperti yang dikemukakan oleh (Kartika, 2018), dan pelatihan digital seperti yang telah dikemukakan oleh (Widyasanti, 2016). Untuk meningkatkan pengetahuan akan sebuah teknologi atau pengetahuan baru, pengabdian akan mengacu pada pola yang telah diterpkan oleh (Kurnianingsih, 2017).

\section{Fase 1}

Tahapan awal dari pelaksanaan kegiatan ini adalah melakukan pertemuan koordinasi dengan ketua dan wakil ketua komunitas augmented reality (KAR) untuk melakukan koordinasi perancangan dan sosialisasi kegiatan pelatihan yang akan dilaksanakan.

\section{Fase 2}

Tahapan selanjutnya adalah melaksanakan pelatihan yang telah disepakati yaitu pelatihan manajemen organisasi dan pelatihan augmented reality. Pelaksanaan pelatihan akan dilaksanakan selama 4 bulan lamanya. 2 bulan pertama akan dilakukan pelatihan di bidang manajemen organisasi sesuai dengan kebutuhan dari komunitas. Adapun materi pelatihan yang akan diberikan di 2 bulan pertama berupa :

Tabel 1. Pelatihan Bulan Agustus Hingga September

Bulan Agustus - September 2018 Pelatihan Manajemen Organisasi 1 Manajemen Organisasi

- Maksud dan Tujuan Organisasi

- Mengapa Harus Berorganisasi

- Manfaat Organisasi

- Motivasi Berorganisasi

- Struktur Organisasi

- Job Description dari Pengurus Organisasi

- Bagaimana Membangun Sebuah Organisasi yg Solid \& Produktif

- Mengatasi Konflik

- Interaksi dan Komunikasi di Internal Organisasi

\section{Membangun Teknik Berbicara dan Presentasi}

- Teknik Berbicara di Depan Umum

- Meningkatkan Rasa Percaya Diri Untuk Berbicara di Depan Umum

- Protokoler Dalam Berpidato dan Memandu Acara

Pelatihan Manajemen Organisasi 2

Menyusun Program Kerja

- Penyusunan Program Kerja Yang Aspiratif Kreatif dan Inovatif

- Goal Setting 
- Planning \& Organizing

- Time Schedulle

- Kepanitiaan Protokoler Dalam Berpidato dan Memandu Acara

\section{Kesekretariatan}

- Tata Cara Surat Menyurat

- Filing \& Administrasi Organisasi

- Teknik Pembuatan Proposal

- Teknik Pembuatan LPJ

Berikut adalah materi pelatihan

kedua di bulan Oktober-Nopember 2018 berupa :

Tabel 2. Pelatihan Bulan Oktober Hingga Nopember

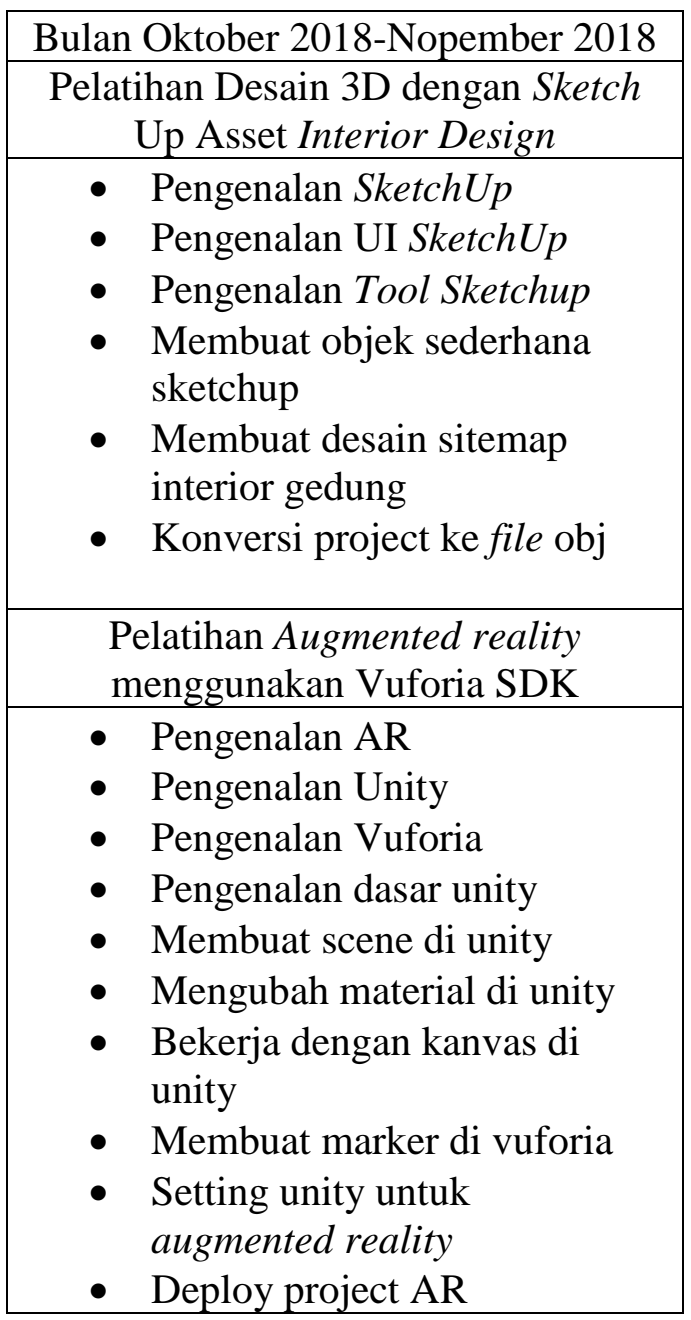

\section{Tahapan Akhir}

Tahapan Akhir pada program pengabdian ini adalah sebagai tindak lanjut evaluasi dari pelaksanaan pelatihan kepada peserta pelatihan, untuk melihat tingkat penyerapan pengetahuan dari hasil pemberian pelatihan.

\section{Hasil dan Pembahasan}

Pengabdian kepada masyarakat merupakan salah satu dari tiga dharma atau tugas pokok dari dosen tetap di perguruan tinggi Universitas Trilogi, disamping pengajaran dan penelitian. Pengabdian masyarakat merupakan kegiatan yang memanfaatkan ilmu pengetahuan dalam upaya memberikan sumbangan demi kemajuan masyarakat. Pengertian mengenai pengabdian masyarakat secara filosofis sesungguhnya dapat berkembang dan dikembangkan sesuai dengan persepsi dan tergantung pada dimensi ruang dan waktu sesuai dengan kebutuhan mitra pengabdian. Topik dari pengabdian masyarakat yang berjudul "Peningkatan Manajemen Organisasi di Komunitas Augmented Reality" dilaksanakan sesuai dengan kebutuhan dari mitra pengabdian yaitu bagaimana mengelola sebuah organisasi dengan baik dan tepat. Seiring dengan permasalahan tersebut, latar belakang dan keilmuan dari tim pengabdian sudah sesuai dengan konsep dari kegiatan pengabdian. Kegiatan pertama sesuai dengan jadwal pengabdian yaitu melakukan kegiatan sosialisasi manajemen organisasi pada Komunitas Augmented Reality. Materi kegatan dari rangkaian pengabdian pertama ini berupa pemaparan dari 
berbagai macam narasumber yang terdiri dari tim pengabdian yaitu :

1. Budi Arifitama.,ST.,MMSI dengan topik membagun manajemen organisasi yang baik

2. Ade Syahputra.,ST.,M.Inf.Comm.Te ch.Mgmt dengan topik membangun anggaran dengan tepat.

Acara dimulai dengan registrasi ulang para peserta sosialisasi dan kemudian langsung dibuka oleh ketua Komunitas Augmented Reality, dan menyambut serta memberikan apresiasi kepada narasumber dari Prodi Teknik Informatika Universitas Trilogi atas kesesdiaanya dalam memberikan materi tentang pengelolaan manajemen organisasi untuk Komunitas Augmented Reality. Sesi kegiatan pengabdian ini dilakasanakan dengan teknik ceramah yang disampaikan oleh narasumber pertama yaitu dengan materi tentang manajemen organisasi. Adapun isi materi yang disampaikan pada kegiatan ini adalah seperti pada tabel 3.

Tabel 3. Materi Pengabdian

Manajemen Organisasi

\begin{tabular}{|l|l|}
\hline No & \multicolumn{1}{|c|}{ Materi Pengabdian } \\
\hline 1 & $\begin{array}{l}\text { Manajer dan Organisasi dalam } \\
\text { Komunitas }\end{array}$ \\
\hline 2. & $\begin{array}{l}\text { Proses Manajemen Organisasi } \\
\text { dalam Komunitas }\end{array}$ \\
\hline 3. & Jenis-Jenis Manajemen \\
\hline 4. & Managerial Roles \\
\hline
\end{tabular}

Kegiatan selama selama kegiatan pengabdian tersebut dapat dilihat pada gambar 1

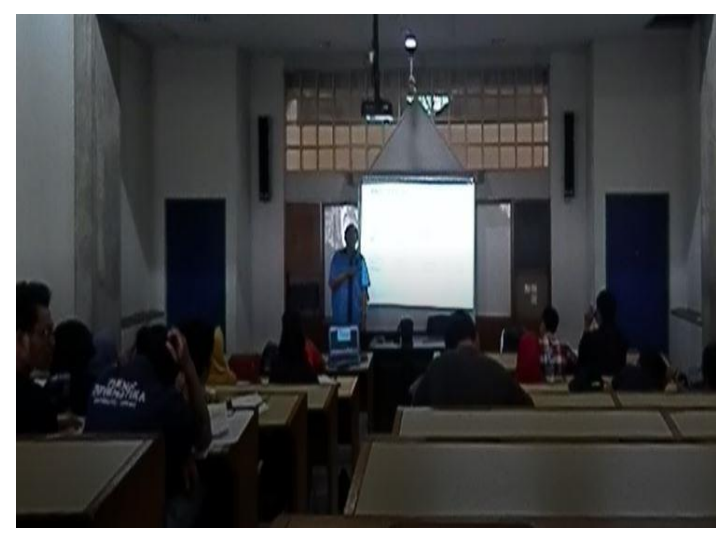

Gambar 1. Sosialisasi Manajemen Organisasi Yang Baik Bagi Komunitas

Kemudian kegiatan kedua pada acara kegiatan pengabdian yang pertama adalah pemberian materi penyusunun anggaran dan kegiatan dari Komunitas Augmented Reality yang dilaksanakan oleh bapak Ade Syahputra seperti yang dapat dilihat pada gambar 2

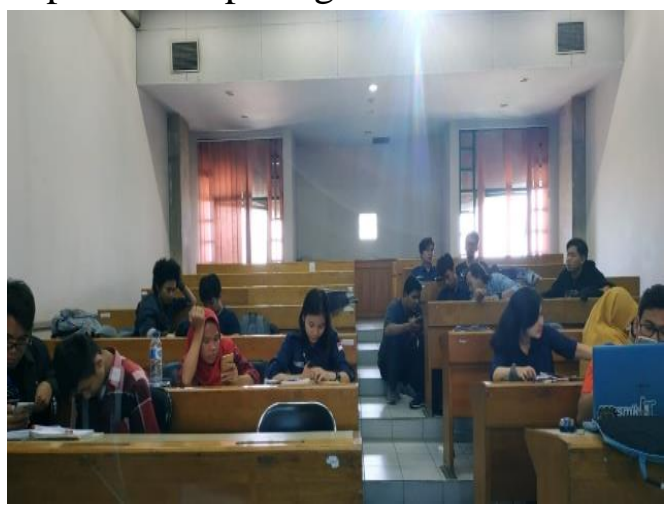

Gambar 2. Suasana Pengabdian Manajemen Organisasi Komunitas

Untuk mengukur seberapa baik materi yang disampaikan dapat terserap oleh para peserta pelatihan, maka diakhir sesi para peserta diharusakan untuk mengisi lembar feedback sebagai masukan atas pelaksanaan kegiatan pengabdian tersebut. Adapun hasil dari feedback adalah pada tabel 4 . 
Tabel 4. Feedback Peserta Pelatihan Manajemen Organisasi

\begin{tabular}{|c|l|c|}
\hline No & \multicolumn{1}{|c|}{ Keterangan } & Nilai \\
\hline 1 & $\begin{array}{l}\text { Pemahaman tentang } \\
\text { organisasi anda } \\
\text { bertambah }\end{array}$ & 91 \\
\hline 2 & $\begin{array}{l}\text { Anda merasa } \\
\text { pengetahuan anda } \\
\text { bertambah dari materi } \\
\text { yang telah diberikan? }\end{array}$ & 85 \\
\hline 3 & $\begin{array}{l}\text { Anda merasa materi } \\
\text { manajemen organisasi } \\
\text { sangat penting buat } \\
\text { anda kedepanya? }\end{array}$ & 93 \\
\hline 4 & $\begin{array}{l}\text { Anda merasa } \\
\text { penjelasan } \\
\text { instruktur sudah jelas }\end{array}$ & 84 \\
\hline 5 & $\begin{array}{l}\text { Anda merasa tertarik } \\
\text { dalam ikut kegiatan } \\
\text { berorganisasi }\end{array}$ & 83 \\
\hline 6 & $\begin{array}{l}\text { Anda merasa pelatihan } \\
\text { ini bermanfaat untuk } \\
\text { diterapkan dalam } \\
\text { organisasi }\end{array}$ & 89 \\
\hline 7 & $\begin{array}{l}\text { Anda merasakan } \\
\text { mendapatkan manfaat } \\
\text { dari hasil pelatihan }\end{array}$ & $\begin{array}{l}\text { 879 } \\
\text { Anda merasa dapat } \\
\text { berorganisasi dengan } \\
\text { baik? }\end{array}$ \\
\hline 9 & $\begin{array}{l}\text { Anda merasa mengerti } \\
\text { hal yang perlu } \\
\text { dipersiapkan dalam } \\
\text { berorganisasi? }\end{array}$ & 88 \\
\hline 10 & $\begin{array}{l}\text { Anda merasa akan } \\
\text { pentingnya pelatihan } \\
\text { ini? }\end{array}$ & 90 \\
\hline Total & Rerata \\
\hline 8 & $\begin{array}{l}\mathbf{8 7} \\
\text { anda }\end{array}$ \\
\hline
\end{tabular}

Berdasarkan dari hasil Tabel 4, hasil terendah dari tabel adalah 83 dan hasil tertinggi adalah 93 dimana dapat diasumsikan bahwa penerimaan informasi kepada peserta pelatihan telah cukup berhasil. Kegiatan pengabdian yang kedua yang dilaksanakan di Komunitas Augmented Reality berupa pelatihan pembuatan aplikasi mobile dengan memanfaatkan augmented reality seperti beberapa produk penelitian yang telah dikembangkan oleh (Arifitama, 2015). Metode pelaksanaan kegiatan pengabdian ini dilaksanakan dengan cara memberikan pelatihan di secara bertahap dan secara bersamaan dengan melakukan observasi kepada para peserta pelatihan yang sedang mengikuti pelatihan secara terpandu. Pengamatan yang dilakukan pada program pengabdian ini adalah dengan melihat perkembangan dari peserta pada saat mengerjakan tutorial pembuatan aplikasi. Observasi menjadi alat penyelidikan ilmiah yang digunakan sebagai alat ukur dalam sebuah program pengabdian yang direncanakan secara sistematik dan teratur (Jahoda, 1958).

Adapun rincian materi kegiatan dari kegiatan pengabdian kedua ini adalah dapat dilihat pada Tabel 5.

Tabel 5. Materi Pelatihan Pembuatan Aplikasi Augmented Reality

\begin{tabular}{|l|l|}
\hline No & $\begin{array}{l}\text { Materi Pelatihan Pembuatan } \\
\text { Aplikasi Augmented Reality }\end{array}$ \\
\hline 1 & $\begin{array}{l}\text { Pengenalan augmented reality, } \\
\text { yang mengupas secara umum } \\
\text { sejarah perkembangan } \\
\text { teknologi augmented reality } \\
\text { dari awal penemuanya. }\end{array}$ \\
\hline 2 & $\begin{array}{l}\text { Klasifikasi bidang industri } \\
\text { yang telah menggunakan } \\
\text { teknologi augmented reality }\end{array}$ \\
\hline 3 & $\begin{array}{l}\text { Peluang yang dapat dilakukan } \\
\text { dari beberapa bidang di industri } \\
\text { terkait dengan teknologi } \\
\text { augmented reality }\end{array}$ \\
\hline
\end{tabular}




\begin{tabular}{|c|c|}
\hline 4 & $\begin{array}{l}\text { Pengenalan antarmuka dari } \\
\text { Unity, kegiatan ini } \\
\text { dilaksanakan sebagai } \\
\text { pengetahuan dasar peserta } \\
\text { mengenai dasar aplikasi unity } \\
\text { sebagai pengemangan aplikasi } \\
\text { augmented reality }\end{array}$ \\
\hline 5 & $\begin{array}{l}\text { Pengenalan tool dasar unity, } \\
\text { kegiatan ini dilaksanakan } \\
\text { sebagai pengenalan dasar tool } \\
\text { dan komponen untuk dapat } \\
\text { melakukan manipulasi } \\
\text { pengembangan aplikasi }\end{array}$ \\
\hline 6 & $\begin{array}{l}\text { Pembuatan marker di Vuforia } \\
\text { SDK, kegiatan ini dilaksanakan } \\
\text { sebagi pembuatan marker atau } \\
\text { penanda dari aplikasi } \\
\text { augmented reality yang } \\
\text { berfungsi sebagai penanda } \\
\text { kehadiran dari objek } \\
\text { augmented reality }\end{array}$ \\
\hline 7 & $\begin{array}{l}\text { Integrasi antara marker Vuforia } \\
\text { SDK dan Unity, kegiatan ini } \\
\text { dilaksanakan sebagai bentuk } \\
\text { penyatuan antara marker yang } \\
\text { telah dibuat agar dapat } \\
\text { digunakan dan dimanipulasi } \\
\text { sesuai kebutuhan dari } \\
\text { pengembangan aplikasi } \\
\text { augmented reality. }\end{array}$ \\
\hline 8 & $\begin{array}{l}\text { Pelatihan pembuatan aset objek } \\
3 \text { dimensi di unity }\end{array}$ \\
\hline 9 & $\begin{array}{l}\text { Pelatihan penerapan objek } 3 \\
\text { dimensi kedalam augmented } \\
\text { reality }\end{array}$ \\
\hline 10 & $\begin{array}{l}\text { Melakukan proses deployment } \\
\text { aplikasi ke format aplikasi } \\
\text { mobile dengan ekstensi .apk }\end{array}$ \\
\hline
\end{tabular}

Susasana dari pelatihan augmented reality dapat dilihat pada gambar 3.

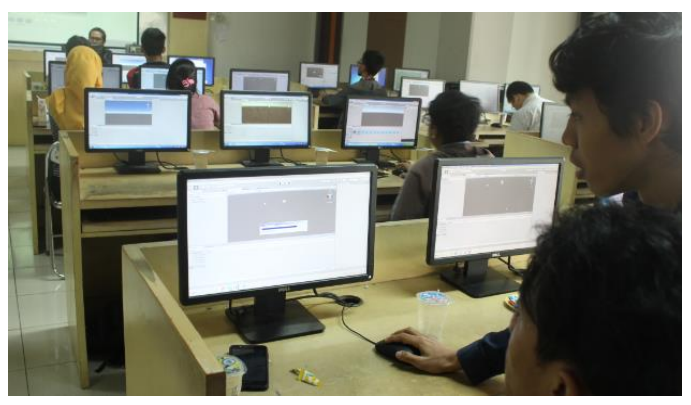

Gambar 3. Suasana Pelatihan Membuat Augmented Reality

Hasil dari pelatihan yang dilaksanakan sesuai pada gambar, adalah berupa sebuah produk pengembangan aplikasi augmented reality dasar seperti yang ditunjukan pada gambar 4

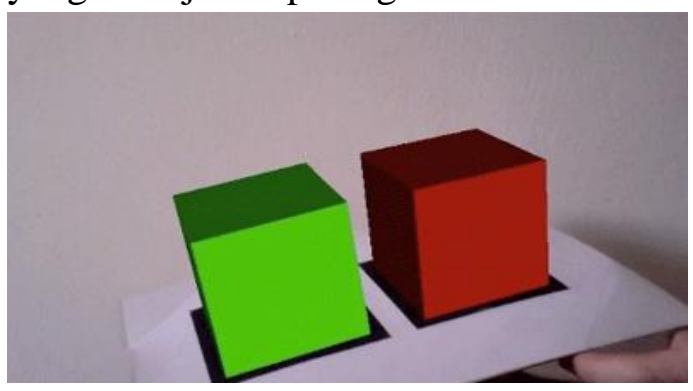

Gambar 4. Hasil Produk

\section{Pengembangan Augmented Reality}

Untuk mengetahui aktivitas dan kondisi masyarakat maka dilakukan pengamatan, yang sesuai dengan lembar observasi yang telah dibuat dimana lembar observasi. Hasil dari pengamatan selama pelaksanaan pelatihan ini menunjukan bahwa dari total 20 peserta, seluruh peserta mampu menghasilkan produk dasar berupa aplikasi augmented reality yang dijalankan pada perangkat mobile.

\section{Kesimpulan}

Kesimpulan dari pelaksanaan kegiatan program pengabdian 
masyakarat yaitu peningkatan keterampilan manajemen organisasi dan keterampilan membuat augmented reality pada anggota Komunitas Augmented Reality adalah, seluruh peserta pelatihan berhasil mampu memahami bagaimana mengelola organisasi yang baik dan mampu membuat dasar aplikasi augmented reality.

\section{Daftar Pustaka}

Arifitama, B. 2015. 'Pengembangan Alat Peraga Pengenalan Tata Surya Bima Sakti Menggunakan Augmented Reality di PAUD', Jurnal SISFO, vol. 5, no. 4, pp. 446-453.

Jahoda, M. (1958) Current Concept of Positive Mental Health, New York: Basic Books.

Kartika, M. 2018. 'Pelatihan dan Pendampingan Pengolahan Komoditi Kelapa', Jurnal Pengabdian dan Pemberdayaan Masyarakat.

Kurnianingsih. 2017. 'Upaya

Peningkatan Kemampuan Literasi

Digital bagi Tenaga Perpustakaan

Sekolah dan Guru di Wilayah Jakarta Pusat Melalui Pelatihan Literasi Informasi', Jurnal Pengabdian Kepada Masyarakat (JPKM).

Widyasanti, A. 2016. 'Upaya Pemberdayaan Masyarakat Melalui Pelatihan Pembuatan Produk Sabun Berbasis Komoditas Lokal Di Kecamatan Sukamantri Ciamis', Jurnal Aplikasi Ipteks untuk Masyarakat. 